\title{
Investigation of Antioxidant Capacity and Some Bioactive Compounds of Iranian Pistachio (Pistachio vera L.) Cultivars
}

\author{
Gholamhossein DAVARYNEJAD ${ }^{1 *}$, STEFANOVITS-BÁNYAI ${ }^{2}$, Peter Tamas NAGY³ \\ ${ }^{1}$ Ferdowsi University of Mashhad, Faculty of Agriculture, Department of Horticultural Science, P.O. \\ Box91775-1163, Mashbad, Iran; davarynej@um.ac.ir ( ${ }^{*}$ corresponding author) \\ ${ }^{2}$ Corvinus University of Budapest, Faculty of Food Science, Department of Applied Chemistry, P.O. Box 53, Budapest, H-1518, Hungary \\ ${ }^{3}$ Institute of Environmental Sciences, Faculty of Natural Resources Management and Rural Development, Károly Róbert College, Gyöngyös, Hungary
}

\begin{abstract}
Edible nuts have an increasing role in human diet. Pistachio is a popular but less known kind of edible nut nevertheless it is rich in health benefiting nutrients, minerals, antioxidants and vitamins. Therefore, this study attempts to determine the antioxidants capacity, total phenolics and amount of some major elements (nitrogen, potassium, calcium and phosphorus), present in the most important Iranian pistachio nut, to enhance the health benefits, and use in breeding programs. For this reason eleven pistachio cultivars ('Akbary', 'Ahmad Aghaii', 'Daneshmandi', 'Kalle Ghoochi 1', 'Kalle Ghoochi 2', 'Garmeh', 'Ohadi 1', 'Ohadi 2', 'Sefid', 'Momtaz', and chance seedling tree ("None-grafted") as control) which are grown in commercial orchards of Fayzabad (Khorasan-e-Razavi) were analyzed for determination of some major elements, antioxidants capacity and total phenolics contents. The results showed that the amounts of the nutrients in $100 \mathrm{~g}$ kernel were within the following ranges: N 2.5-4.1 g, P 355.9-546.6 mg, K 573.6-994.9 mg and Ca 61.5-134.5 mg. Total phenolics content varied from 5.3-9.9 mg gallic acid equivalents in $\mathrm{g}$ fresh weight. The results also showed that the capacity of antioxidant ranged from 1.6-3.7 (mg ascorbic acid equivalents in $\mathrm{g}$ fresh weight). Weak correlation was observed between total phenolic content and total antioxidant capacity $\left(\mathrm{r}^{2}=0.3824\right)$. The result demonstrates that there is adequate variation in major elements, antioxidants capacity and total phenolics contents within pistachio cultivars and hence there is potential for improvement towards enhancing these healthpromoting photochemical in this nuts.
\end{abstract}

Keywords: FRAP, major elements, phytochemicals, total phenolic

\section{Introduction}

As a result of environment pollution there is now an increasing risk of disturbance to the prooxidant-antioxidant balance in the human body (Sies, 1991). Among the protective mechanisms against free radicals, antioxidant vitamins; vitamin $\mathrm{C}$, vitamin $\mathrm{E}$ and $\beta$-carotene are of special interest (Sies, 1991). Nut Fruits are beneficial to human health and contribute to the prevention of degenerative processes. Studies related to human diet shows that the nuts such as hazelnut (Durak et al., 1999), walnut (Lavedrine et al., 1999; Tapsell et al., 2004) and pistachio nuts (Edwards et al., 1999; Kocyigit et al., 2006) are beneficial for the amelioration of blood plasma antioxidant potential and lipid profiles.

Pistachio 'Pistacia vera' is one of the most important nut commodities as an economic plant with good agricultural characteristics. Besides vitamins and carotenoids, pistachio nuts contain several important phytonutrients such as flavonoids and phenolic acids which have strong antioxidant capacities. The pistachio is becoming increasingly popular nut and is a significant source of nutritional antioxidants, such as: polyphenols, anthocyanins as well as biologically active dietary components.
Chemical composition of pistachio nuts may vary depending upon cultivar, rootstock and maturity at harvest and moisture content. The composition of pistachio kernels of various Iranian cultivars was studied by Kamangar and Farsam (1997). According to their results, the amount of constituent in $100 \mathrm{~g}$ kernel were within the following ranges, oil 55.2-60.5\%, protein 15.0-21.2\%, carbohydrate 14.9-17.7\%, Na 4.0 mg, K 1048-1142 mg, Ca 120-150 mg, P 494-514.5 mg, Fe 5.8-11.4 mg, Cu 1.0-1.4 mg, Mg 157.5-165.0 mg (Kamangar and Farsam, 1997). Bellomo and Fallico (2007) showed that these foods are good sources of antioxidant and phenolic compounds. Goli et al. (2005) compared two different extraction methods to measure the phenolic compound and antioxidants activity of pistachio (solvent and ultrasound-assisted methods) with three different solvents (water, methanol and ethyl acetate) and the results were compared with supercritical fluid extraction.

The diversity of phytochemicals within pistachio cultivars has not been investigated in detail, and studies related to antioxidant activity of these important cultivars are scarce, primarily because most breeding programs aim at improving yield, altering season and resistance to biotic and abiotic factors. Hence, in this study, we aimed 
to evaluation several Iranian pistachio cultivars for major elements, total phenolic content and the antioxidant activity so that superior cultivars could be identified and used for further improvement. The results of this work will help better understanding of the antioxidant activity of different pistachio cultivars.

\section{Materials and methods}

\section{Plant materials}

Nut samples from 15 years old pistachio trees grown at the commercial orchards of Fayzabad (Khorasan-e-Razavi, Iran) were collected at the phenophase of commercial maturity from the following cultivars: 'Akbary', 'Ahmad Aghaii', 'Daneshmandi', 'Kalle Ghoochi 1', 'Kalle Ghoochi 2', 'Garmeh', 'Ohadi 1', 'Ohadi 2', 'Sefid', 'Momtaz', and chance seedling tree as 'None-grafted. The chance seedling tree ('None-grafted') served as a control. Composite samples containing approximately 60 nuts. Harvesting of samples take place September through October, over 3 week as the commercial maturity of cultivars was different.

All eleven cultivars used in this study were grown in the same location under similar horticultural managment. The average yearly precipitation in Fayzabad is about 200 $\mathrm{mm}$, so the orchard was irrigated every 24 days. The cultivars grafted on 'Sefid' seedling and were planted in $3 \times 6 \mathrm{~m}$ layout. The soil in this area is classified as loam with a $\mathrm{pH}$ of 8.2 and contained 5.6 and $5.2 \mathrm{mg} / 100 \mathrm{~g}$ soil of plant available $\mathrm{P}$ and $\mathrm{K}$, respectively. The weeds were treated with herbicides. The orchard was sprayed 4 times against pistachio psylla (Agonoscena pistaciae): 1) just before anthesis, 2) first week of May, 3) third week of June and 4) third week of July with amitraz at $0.2 \%$, volk $1 \%$ was used as a wetting agent.

Nuts from different cultivars with shells were sun dried and stored until they were used for analysis. The shells and kernels were removed manually, just before extraction.

\section{Total phenolic and antioxidant capacity measurement}

Pistachio kernels were grounded. About 1.7-2 g seed powder was macerated in $10 \mathrm{ml}$ of $20 \%$ ethanol solution for $48 \mathrm{~h}$, at the room temperature, then the combined extract was centrifuged at $13,000 \mathrm{~g}$ for $10 \mathrm{~min}$. Clear supernatant was used for analyses.

Total soluble phenols were determined using FolinCiocalteu reagent according to the method of Singleton and Rossi (1965). The content of soluble phenols was calculated from a standard curve obtained with different concentrations of Gallic Acid (GA).

Antioxidant power (mg ascorbic acid/g fresh weight) was measured by the FRAP (Ferric Reducing Ability of Plasma) method (Benzie and Strain, 1996). The method is based on the capability of antioxidants to reduce the Fe (III) ions to $\mathrm{Fe}$ (II) ions in a complex compound (Fe (III)tri-pyridyl triazine). The produced Fe (II) compound is blue colored and its absorbance was measured at $593 \mathrm{~nm}$ in the Department of Applied Chemistry, Faculty of Food Science, Corvinus University of Budapest.

\section{Determination of major elements}

Sample preparing was in accordance with Hungarian standard (MSZ-08-1783-15) in the Institute of Environmental Sciences, Faculty of Natural Resources Management and Rural Development, Hungary. Kernels were digestion with concentrate $\mathrm{HNO}_{3}-\mathrm{H}_{2} \mathrm{O}_{2}$ digester mixture. $5 \mathrm{~g}$ was digested at $120^{\circ} \mathrm{C}$ during three hours in a teflon digestor. Digested samples diluted with distilled water to $100 \mathrm{~cm}^{-3}$. Examined elements, except $\mathrm{N}$ were measured by Thermo Jarrell Ash Polyscan 61E and Thermo Electron Corporation IRIS Intrepid II XDL Inductively coupled plasma emission spectrophotometers (ICP). N content of kernels was determined by Kjeldahl method with a TECATOR 2200 automatic distilator and titrator. From $\mathrm{N}$ content of kernel protein was calculated by using the factor of $\mathrm{N} \times 6.25$.

\section{Statistical analysis}

Data of measurements were recorded and means were compared statistically by LSD test and were plotted using MS Excel 2007.

\section{Results and discussion}

\section{Nitrogen}

Pistachio nuts classified as the foodstuffs that contain the high level of essential main minerals and trace elements. In the available literature data about the content of nitrogen in pistachio cultivars is scant. Kamangar and Farsam (1997) showed that in the mature nut, arginine is a dominant amino acid and the edible kernel is rich in protein.

Nitrogen content of pistachio cultivars is presented in Fig. 1. The nitrogen content varied from 2.58 to 4.12 ( $\mathrm{g} / 100 \mathrm{~g}$ dry weight) in 'Ahmad Aghaii' and 'Kallehghuchi 2 ' cultivars, respectively. The results showed significantly higher concentrations of nitrogen were observed in the 'Kallehghuchi 1', 'Kallehghuchi 2', than in 'Ahmed Aghaii', 'Non-grafted'. Therefore, cultivar had significant effect on kernel nitrogen content.

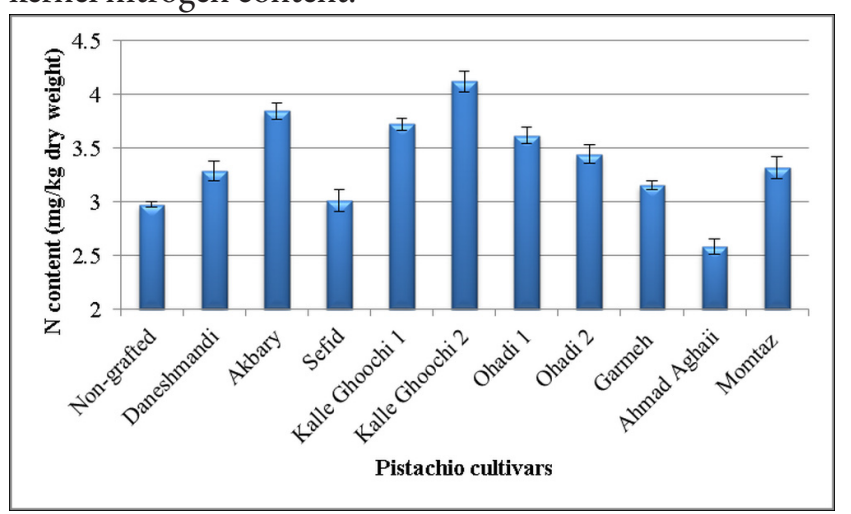

Fig. 1. Nitrogen content ( $\mathrm{mg} / \mathrm{kg}$ dry weight) of Iranian pistachio cultivars 
64

\section{Phosphorus}

Phosphorus is an essential macro-element for plants growth and development required by every cell in the plant tissue. A number of enzymes, hormones and cellsignaling molecules depend on phosphorylation for their activation (Knochel et al., 2006).

Phosphorus content of pistachio cultivars is presented in Fig. 2. 'Kallehghuchi 2', 'Momtaz' and 'Ohadi 2' cultivars contained significantly higher phosphorus in kernels than other examined cultivars. The lowest concentration was found at 'Daneshmandi', 'Non-grafted', 'Kallehghuchi 1 ' and 'Sefid'.

Phosphorus in the examined pistachio cultivars had values in the range of $355.96-546.66(\mathrm{mg} / 100 \mathrm{~g}$ dry weights), which are higher than the values for this element in banana $(26 \mathrm{mg} / 100 \mathrm{~g})$, pineapple $(8 \mathrm{mg} / 100 \mathrm{~g})$ and strawberries $(21 \mathrm{mg} / 100 \mathrm{~g})$. Therefore Pistachio seems to be an excellent phosphorus source in human nutrition. Our results confirm earlier findings that pistachios are rich in phosphorus, which helps the body break down meat and other proteins into amino acids. Phosphorus is necessary for hormone production and to help the body use $B$ vitamins.

Low phosphorus can cause glucose intolerance and abnormally low serum phosphate level (hypophosphatemia). The effects of hypophosphatemia may include loss of appetite, anemia, muscle weakness, bone pain, rickets (in children), osteomalacia (in adults), increased susceptibility to infection (Knochel et al., 2006), numbness and tingling of the extremities and difficulty walking. Severe hypophosphatemia may result in death. Because phosphorus is so widespread in food, dietary phosphorus deficiency is usually seen only in cases of near-total starvation (Knochel $e t$ al., 2006).

Regarding this, eating pistachios may help reduce the risk of developing adult-onset diabetes and above mentioned health problems. However, phosphorus from nuts, seeds and grains is about $50 \%$ less bioavailable than phosphorus from other sources because we lack enzymes (phytases) that liberate phosphorus from phytate (FNB, 1997 a).

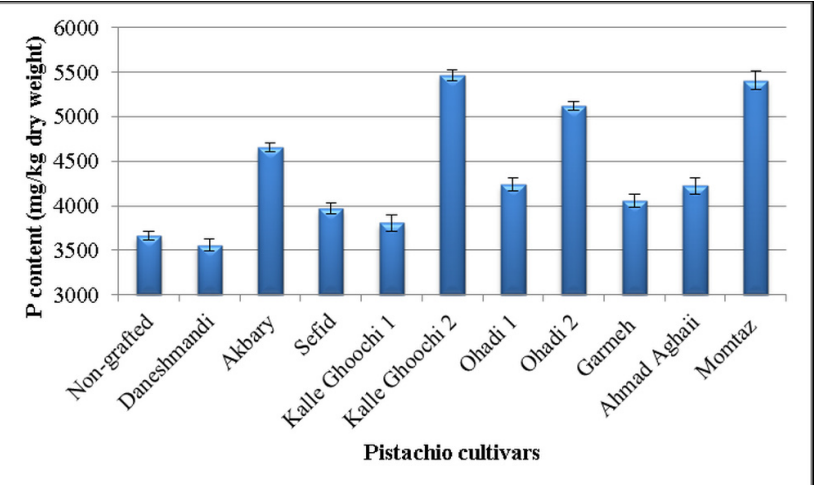

Fig. 2. Phosphorus content (mg/kg dry weight) of Iranian pistachio cultivars

\section{Potassium}

Potassium is the most abundant mineral available in fruits. This element is mainly in combination with the various organic acids. Adequate intake of potassium for adults is $4700\left(\mathrm{mg} \mathrm{day}^{-1}\right)$. Potassium is an essential element for nutrition. It is a cofactor for the activity of pyruvate kinase, an important enzyme in carbohydrate metabolism (Sheng, 2000).

The results of this experiment showed that the average potassium content of examined cultivars is $800 \mathrm{mg} / 100 \mathrm{~g}$ dry weight approximately. Significant differences in potassium content of kernel were observed. The highest amount of potassium belongs to 'Ohadi' by 994.96 (mg/100 g dry weight) and the lowest amount belongs to 'Akbary' with 573.66 (mg/100 g dry weight) (Fig. 3).

Consequently, recommended an increasing potassium intake by increasing consumption of potassium-rich foods, especially fruits, vegetables and nuts. Our results pointed out that consumption of pistachio has main role in prevention of disease.

\section{Calcium}

Calcium has great function in human body as structural element, affected cell signaling and cofactor for enzymes and proteins. Calcium plays a role in mediating the constriction and relaxation of blood vessels (vasoconstruction and vasodilation), nerve impulse transmission, muscle contraction and the secretion of hormones like insulin (FNB, 1997 b).

The results of this experiment showed that the maximum calcium levels in the nut of examined pistachio cultivars were about 134.53 (mg/100 g dry weight) in 'Daneshmandi' and minimum level in 'Momtaz' (61.53 mg/100 g dry weight) (Fig. 4). According to our results, pistachio nuts represent rich and absorbable sources of calcium, also certain vegetables and grains provide calcium. However, the bioavailability of the calcium must be taken into consideration. While the calcium rich plants in the kale family (broccoli, bokchoy, cabbage, mustard and turnip greens) contain calcium that is as bioavailable as that in milk and some food components have been found to inhibit the absorption of calcium and are comparable to values for guava

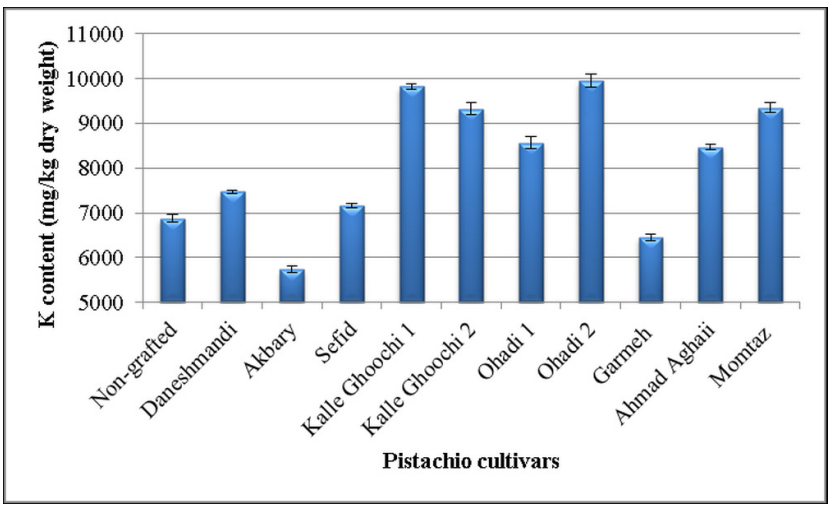

Fig. 3. Potassium content ( $\mathrm{mg} / \mathrm{kg}$ dry weight) of Iranian pistachio cultivars 


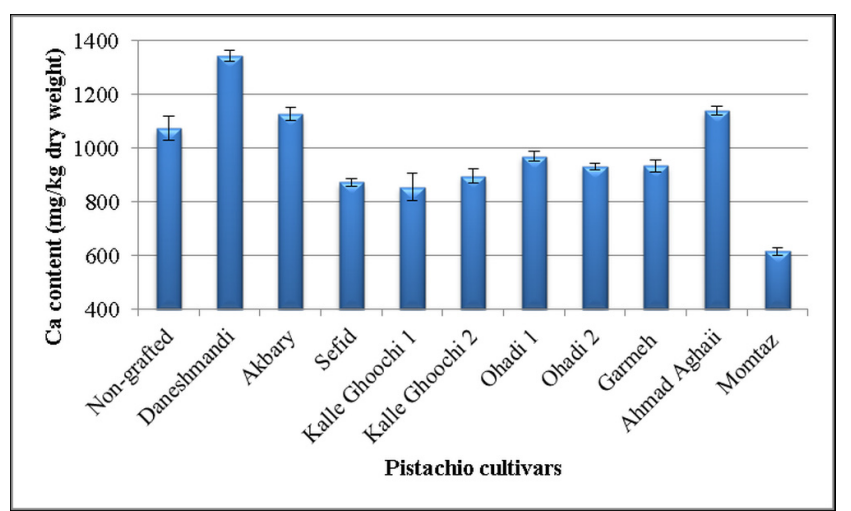

Fig. 4. Calcium content ( $\mathrm{mg} / \mathrm{kg}$ dry weight) of Iranian pistachio cultivars

(23 mg/100 g) and raspberries ( $26 \mathrm{mg} / 100 \mathrm{~g})$. Zizyphus mauritiana contains the highest level of calcium and magnesium with values for the latter element in fruit ranging between 16.7-227 mg/100 g (Weaver et al., 1999).

Though some fruits, such as apricots, pears, peaches, plums and strawberries, contain oxalic acid. The concentration of this acid is not sufficient to reduce the absorption of calcium from the fruit or from other foods eaten together with the fruit. Our results pointed out that Pistachio regards as an excellent calcium source for human diet. Its role is more expressed in vegetarian diet.

Adequate Intake of calcium for adults is $1000 \mathrm{mg}$. day ${ }^{1}$. The combination diet represented an increase of about $800 \mathrm{mg}$ of calcium in day over the control and fruit/vegetable rich diets for a total of about $1200 \mathrm{mg}$ of calcium in day.

\section{Totalphenolics}

Fig. 5 shows the total phenol content of pistachio cultivars. The highest phenolic content was found in 'Nongrafted' pistachio nut extracts with 9.96 (mg/g fresh weight), while 'Akbary' had the lowest $(5.39 \mathrm{mg} / \mathrm{g}$ fresh weight) of total phenol content among the examined cultivars. 'Non-grafted' pistachio nut proved the most remarkably rich phenol content which significantly more than commercial cultivars such as 'Akbary, 'Momtaz', 'Sefid' and 'Daneshmandi' (Fig. 5).

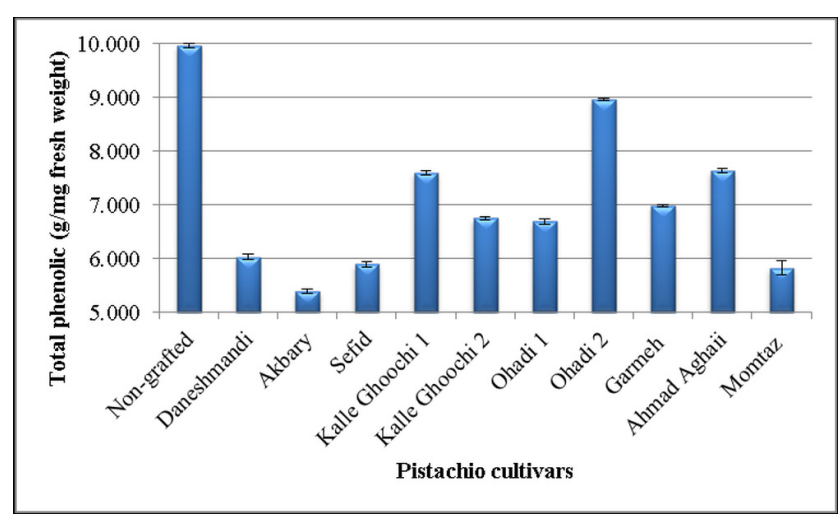

Fig. 5. Total phenolics content ( $\mathrm{mg} / \mathrm{g}$ fresh weight) of Iranian pistachio cultivars
Antioxidant capacity

In our experiments, the total antioxidant capacity of cultivars ranged from $1.60(\mathrm{mg} / \mathrm{g}$ fresh weight) to 3.70 $(\mathrm{mg} / \mathrm{g}$ fresh weight) in 'Akbary' and 'Non-grafted' cultivars, respectively (Fig. 6).

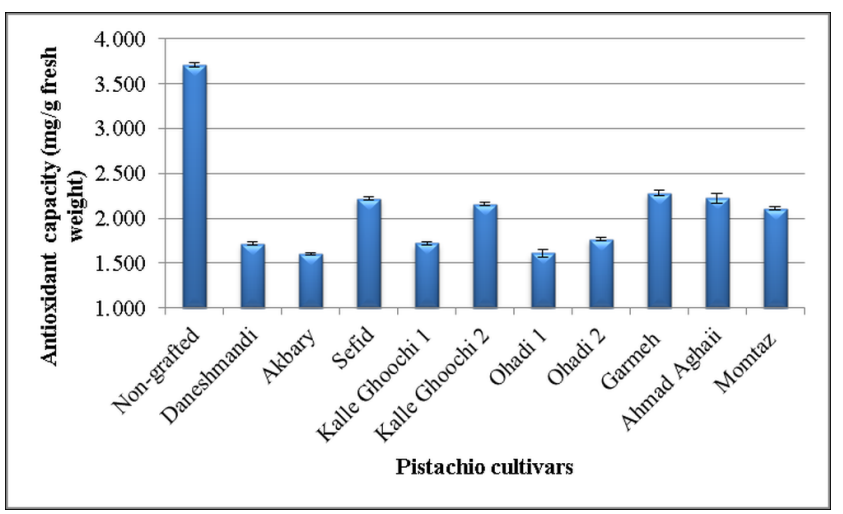

Fig. 6. Antioxidant capacity (mg/g fresh weight) of Iranian pistachio cultivars

Kallithraka et al. (2005) determined the antioxidant activity of the 'Akbary' cultivar as $705.9 \mathrm{mg} / \mathrm{kg}$ and was lower than our finding. Goli et al. (2005) obtained the antioxidant activity of 'Akbary' as $189 \mathrm{mg} / 100 \mathrm{~g}$ which approximately were the same as our findings. The different production area of pistachio cultivars, maturity stage, and different methods of extraction may cause these differences.

\section{Analysis correlation}

According to the results, the antioxidant capacity was correlated to a lower degree with phenol content $\left(\mathrm{r}^{2}=0.38\right)$ in pistachio cultivars (Fig. 7). Arcan and Yemenicioglu (2009) found a close correlation between antioxidant capacity and total phenols $(\mathrm{r}=0.70)$, in nuts (walnut, hazelnut and pistachio). Other researchers found higher correlations of antioxidant activity and total phenols in tomato lines $\left(r^{2}>0.90\right)$ (Hanson et al., 2004), olive

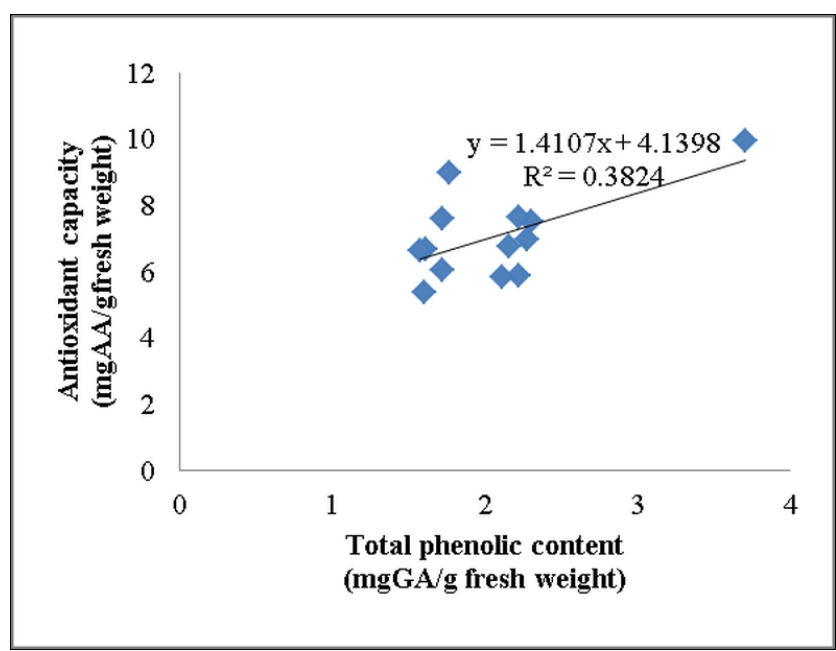

Fig. 7. Correlation between antioxidant activity and phenolic content of all investigated pistachio cultivars 
66

oil samples $\left(\mathrm{r}^{2}=0.86\right)$ (Sanchez et al., 2007), plums (Chun and Kim, 2004; Kim et al., 2003 a). In our study results indicate that antioxidants capacity is less closely correlated with the phenolic content in examined pistachio cultivars, although this can be the result of different extraction and analysis methods.

\section{Conclusion}

The bioactive compounds and antioxidant capacity are important quality parameters of pistachio, due to the importance of these nutrition values to humans. These components in pistachio vary greatly with the cultivars, maturity, production area, seasonal conditions and yield of the nuts. Therefore, we attempt to determine the amount of some major elements (nitrogen, potassium, calcium and phosphorus), total phenolics and antioxidants capacity present in the most important Iranian pistachio nut fruits, to use in breeding programs to enhance the health benefits. The results represent that nitrogen, phosphorus, potassium, calcium, total phenolics content and antioxidant capacity of examined pistachio cultivars which are rich sources of different essential elements and their consumption in human dietary is beneficial to human health and can provide necessary dose of elements needed by body. According to this results pistachio kernels regarded as excellent rich food for human diet. Relationship between antioxidant capacity and phenolic content of pistachio cultivars gave a result to explain that the antioxidant activity of pistachio cultivars $(n=13)$ have a relation with the phenol content.

\section{Acknowledgements}

We gratefully thank Ferdowsi University of Mashhad, for supporting this work by the grants Project.

\section{References}

Arcan I, Yemenicioglu A (2009). Antioxidant activity and phenolic content of fresh and dry nuts with or without the seed coat. J Food Comp Anal 22:184-188.

Bellomo MG, Fallico B (2007). Anthocyanins, chlorophylls and xanthophylls in pistachio nuts (Pistacia vera) of different geographic origin. J Food Comp Anal 20:352-359.

Benzie IIF, Strain JJ (1996). The ferric reducing ability of plasma (FRAP) as a measuring of "antioxidant power": The FRAP assay. Anal Biochem 239:70-76.

Durak I, Koksal I, Kacmaz M, Buyukkocak S, Imen B, Ozturk HS (1999). Hazelnut supplementation enhances plasma antioxidant potential and lowers plasma cholesterol levels. Clinica Chimica Acta 284:113-115.

Edwards K, Kwaw I, Matud J, Kurtz I (1999). Effect of pistachio nuts on serum lipid levels in patients with moderate hypercholesterolemia. J Amer College Nutr 18:229-232.

FNB (1997 a) Food and nutrition board, Institute of medicine, Phosphorus, Dietary reference intakes: Calcium, Phosphorus, Magnesium, Vitamin D and Fluoride, Washington D.C., National Academy Press, 146-189 p.
FNB (1997 b). Food and nutrition board, Institute of medicine, Calcium, Dietary reference intakes: Calcium, Phosphorus, Magnesium, Vitamin D and Fluoride, Washington D.C., National Academy Press, 71-145 p.

Chun OK, Kim DO (2004). Consideration on equivalent chemicals in total phenolic assay of chlorogenic acid-rich plums. Food Res Int 37:337-342.

Goli AH, Barzegar M, Sahari MA (2005). Antioxidant activity and total phenolic compounds of pistachio (Pistachia vera) hull extracts. Food Chem 92:521-525.

Hanson PM, Yang R, Wu J, Chen J, Ledesma D, Tsou SCS (2004). Variation for antioxidant activity and antioxidants in tomato. J Amer Soc Hort Sci 129:704-711.

Kamangar T, Farsam H (1997). Chemical composition of pistachio kernels of various Iranian origins. J Food Sci 42:11351136.

Kim DO, Chun OK, Kim YJ, Moon HY, Lee CY (2003 a). Quantification of polyphenolics and their antioxidant capacity in fresh plums. J Agr Food Chem 51:6509-6515.

Knochel JP (2006). Phosphorus, p. 3-37. In: Shils ME, Shike M, Ross AC, Caballero B, Cousins RJ (Eds.). Modern nutrition in health and disease, Baltimore.

Kocyigit A, Koylu AA, Keles H (2006). Effect of pistachio nuts consumption on plasma lipid profile and oxidative status in healthy volunteers. Nutr Metab Cardi Dise 16:202-209.

Lavedrine F, Zmirou D, Ravel A, Balducci F, Alary J (1999). Blood cholesterol and walnut consumption: a cross-sectional survey in France. Preventive Medicine 28:333-339.

MSZ-08-1783-15 (1985). Nagyteljesítményű műszersorok alkalmazása a növényvizsgálatokban, Növényi anyagok fémtartalmának mennyiségi meghatározása ICP módszerrel, Hungarian Standards Institution, Ministry of Agriculture, Budapest (in Hungarian).

Sanchez CS, Gonzalez AM, Acia-Perrilla MC, Ranados JJ, Dela-Serrana HL, Martiez MC (2007). Different radical scavenging tests in virgin olive oil and their relation to the total phenol content. Analyt Chim Acta 593:103-107.

Sheng HW (2000). Sodium, chloride and potassium, 686-710 p. In: Stipanuk M (Eds.). Biochemical and physiological aspects of human nutrition, Philadelphia W.B.

Sies H (1991). Oxidative Stress: Oxidant and Antioxidant. Academic Press, London Cited by: Remenyik J, Hajnalka L, Duda. L (2008). Antioxidant capacity of some red sweet pepper lines and varieties. Stara Lesna Slovakia. 36:1-4.

Singleton VL, Rossi JA (1965). Colorimetry of total phenolics with phosphomolybdic-phosphotunstic acid reagents. Am J Enol Vitict 16:144-158.

Tapsell LC, Gillen LJ, Patch CS, Batterham M, Owen A, Bare M, Kennedy M (2004). Including walnuts in a low-fat/ modified-fat diet improves HDL cholesterol-to-total cholesterol ratios in patients with type 2 diabetes. Diabetes Care 27:2777-2783.

Weaver CM, Heaney RP (1999). Calcium, 141-155 p. In: Shils M, Olson JA, Shike M, Ross AC (Eds.). Modern nutrition in health and disease, Baltimore. 